\title{
Change in the Physiological and Biochemical Aspects of Tomato Caused by Infestation by Cryptic Species of Bemisia tabaci MED and MEAM1
}

\author{
Claudia Aparecida de Lima Toledo ${ }^{1, * \mathbb{D}}$, Franciely da Silva Ponce ${ }^{1}$, Moisés Daniel Oliveira ${ }^{2}$, \\ Eduardo Santana Aires ${ }^{1}$ (D), Santino Seabra Júnior ${ }^{3}$, Giuseppina Pace Pereira Lima ${ }^{4}$ \\ and Regiane Cristina de Oliveira ${ }^{2}$
}

1 Department of Horticulture, São Paulo State University (UNESP), Botucatu 18600-950, Brazil; franciely.ponce@unesp.br (F.d.S.P.); e.aires@unesp.br (E.S.A.)

2 Crop Protection Department, São Paulo State University (UNESP), Botucatu 18600-950, Brazil; moisesdanielmdo@gmail.com (M.D.O.); regiane.cristina-oliveira@unesp.br (R.C.d.O.)

3 Department of Agronomy, State University of Mato Grosso, Nova Mutum 78450-000, Brazil; santinoseabra@hotmail.com

4 Department of Chemistry and Biochemistry, Institute of Biosciences, Sao Paulo State University (UNESP), Botucatu 18618-970, Brazil; gpplima@ibb.unesp.br

* Correspondence: claudia.lima.toledo@gmail.com; Tel.: +55-14-3880-7690

Citation: de Lima Toledo, C.A.; da Silva Ponce, F.; Oliveira, M.D.; Aires, E.S.; Seabra Júnior, S.;

Lima, G.P.P.; de Oliveira, R.C. Change in the Physiological and Biochemical

Aspects of Tomato Caused by Infestation by Cryptic Species of Bemisia tabaci MED and MEAM1. Insects 2021, 12, 1105.

https://doi.org/10.3390/

insects12121105

Academic Editor: Rosemary Collier

Received: 9 October 2021

Accepted: 12 November 2021

Published: 10 December 2021

Publisher's Note: MDPI stays neutral with regard to jurisdictional claims in published maps and institutional affiliations.

Copyright: (c) 2021 by the authors. Licensee MDPI, Basel, Switzerland. This article is an open access article distributed under the terms and conditions of the Creative Commons Attribution (CC BY) license (https:/ / creativecommons.org/licenses/by/ $4.0 /)$.
Simple Summary: Bemisia tabaci is a polyphagous pest with cryptic species that infest various agricultural crops worldwide. Among the cryptic species, MED and MEAM1 are the most invasive, causing large production losses due to the feeding and transmission of the virus. We aimed to analyze the influence of these insects on the physiology and biochemistry of tomato. We found that the cryptic species MED caused considerable reduction in $\mathrm{CO}_{2}$ assimilation rates, stomatal conductance, and instantaneous carboxylation efficiency. Furthermore, plants infested with MED showed high activity of the enzymes peroxidase and polyphenol oxidase, which are considered expressions of plant defense. In contrast, plants infested with MEAM1 showed low peroxidase activity, which may result in a less lignified feeding place.

Abstract: Infestation by Bemisia tabaci (Gennadius) (Hemiptera: Aleyrodidae) causes damage to tomatoes with production losses of up to $100 \%$, affecting the physiological and biochemical aspects of host plants. The objective of this study was to analyze the influence of infestation of cryptic species of B. tabaci MED and MEAM1 on the physiological and biochemical aspects of tomato. Tomato plants 'Santa Adélia Super' infested with B. tabaci (MED and MEAM1), and non-infested plants were evaluated for differences in gas exchange, chlorophyll - a fluorescence of photosystem II (PSII), and biochemical factors (total phenols, total flavonoids, superoxide dismutase-SOD, peroxidase-POD, and polyphenol oxidase-PPO). Plants infested with B. tabaci MED showed low rates of $\mathrm{CO}_{2}$ assimilation and stomatal conductance of $55 \%$ and $52 \%$, respectively. The instantaneous carboxylation efficiency was reduced by $40 \%$ in MED and by $60 \%$ in MEAM1 compared to the control. Regarding biochemical aspects, plants infested by MED cryptic species showed high activity of POD and PPO enzymes and total phenol content during the second and third instars when compared to control plants. Our results indicate that B. tabaci MED infestation in tomato plants had a greater influence than $B$. tabaci MEAM1 infestation on physiological parameters $\left(\mathrm{CO}_{2}\right.$ assimilation rate (A), stomatal conductance ( $g s)$, and apparent carboxylation efficiency (A/Ci)) and caused increased activity of POD and PPO enzymes, indicating plant resistance to attack. In contrast, B. tabaci MEAM1 caused a reduction in POD enzyme activity, favoring offspring performance.

Keywords: enzymes; insect-plant relationships; photosynthesis; Solanum esculentum 


\section{Introduction}

Tomato (Solanum esculentum L.) is the second most important vegetable crop in the world because of its production and consumption. The main risk for tomatoes is pest in-festation, which can cause losses of up to $100 \%$ of production [1,2].

The whitefly, Bemisia tabaci (Gennadius) (Hemiptera: Aleyrodidae), is one of the largest phytosanitary challenges both in Brazil and globally, infesting crops in 60 countries and colonizing more than 600 plant species. B. tabaci is a complex cryptic group, with 44 sister species described, of which MED and MEAM1 are the most invasive [3]. Differentia-tion between these species is based on biochemical markers, choice of host plants, susceptibility to insecticides, ability to cause disturbances in the host plant, virus transmission, and endosymbiont types [4-7].

Losses caused by B. tabaci are related to direct damage, which is caused by the feeding process through the suction of phloem sap and injection of toxins. In addition, indirect damage occurs through viral transmission [8,9].

Plants perceive attacks by insect pests through compounds released in saliva, known as elicitors, and cause depolarization of the plasma membrane, followed by an increase in $\left[\mathrm{Ca}^{2+}\right]_{c y t}$ and production of reactive oxygen species (ROS). The presence of $\mathrm{Ca}^{2+}$ in the cyto-sol activates calcium-dependent protein kinases and mitogen-activated protein kinases (MAPK) [10,11].

In response to insect attacks, plants can use induced or constitutive resistance. Induced resistance makes the host plant less attractive and nutritious to pest insects, triggering plant-wide (systemic) responses. In addition, induced resistance can alert neighboring plants to insect attacks. Constitutive defense, such as trichomes, is present regardless of external stimuli $[12,13]$.

The ROS are generated through the plant's immune response, mediating the interactions of constitutive and induced defenses, resulting in phytohormone activation. However, at high concentrations, they degrade the structures of proteins, DNA, and other organelles. The degradation of ROS occurs through two systems, enzymatic and non-enzymatic, the enzymatic being through antioxidant enzymes (superoxide dismutase (SOD), catalase, and peroxidase) that participate in several biochemical reactions in plants [14-16]. SOD catalyzes the dismutation reaction of superoxide $\left(\mathrm{O}_{2}{ }^{-*}\right)$ into $\mathrm{H}_{2} \mathrm{O}_{2}$, and peroxidase (POD) and catalase (CAT) act on the peroxide to reduce it [12].

Peroxidase (POD) catalyzes the formation of lignins and oxidative phenols, which help to strengthen the cell structure. In contrast, Catalase (CAT) provides increased resistance to the cell wall and acts as a signal in the induction of defense genes [17]. In addition to antioxidant enzymes, there are defense enzymes such as polyphenol oxidase (PPO), which oxidize phenols into quinones and interact with the amino acid nucleotide side chain, causing the crosslinking of proteins that become unavailable to insects [18]. Phenylalanine ammonia lyase (PAL) is an enzyme involved in the biosynthesis of phytoalexins and lignins, which increases plant resistance. Furthermore, the increase in PAL levels leads to the accumulation of phenolic compounds, as this enzyme is involved in the synthesis of phenolic compounds [19]. The enzymes PPO, SOD, and CAT are involved in plant resistance to attack by herbivorous insects; therefore, the greater their activity in plants, the greater is the level of plant resistance to insect attack [20].

In Brazil, the invasion of MED in 2014 made it difficult to manage whitefly in cropping systems, as whitefly control is performed with the use of synthetic insecticides, and these have dosage rate on the package insert directed to B. tabaci MEAM1. Furthermore, identification of cryptic species requires molecular analysis techniques. The species $B$. tabaci MED and MEAM1 differ in host plant choice and insecticide susceptibility $[7,21,22]$, where the use of insecticides to control the whitefly is considered one of the main factors related to the displacement of MEAM1 by MED in cultivated areas [23]. It is also known that, in Brazil, MED has an increased preference for sweet pepper, which is demonstrated by field collections in São Paulo, with only MED infestation in sweet pepper plants. In tomatoes, there was a proportion of both species in different cropping systems [24]. In a 
competitiveness study in tomato, MEAM1 displaced MED in insecticide-free environments after four generations [25].

In this sense, because of the differences between the cryptic species regarding the choice of the host plant, the hypothesis in this study is that infestation by cryptic species of B. tabaci (MED and MEAM1) shows different damage characteristics (physiological and biochemical) in the host plants, which could provide insights to explain the lowered preference of MED for tomato. Thus, the objective was to analyze the influence of feeding by cryptic species of $B$. tabaci MED and MEAM1 on the physiological and biochemical aspects of tomato.

\section{Material and Methods}

\subsection{Identification of Cryptic Whitefly Species}

Molecular analysis was performed by extracting total nucleic acids from individual whiteflies using the modified chelex method [26]. Individual samples of DNA were amplified by polymerase chain reaction (PCR) using the primer pair Bem23: Bem23F (5'-CGGAGCTTGCGCCTTAGTC-3') and Bem23R (5'-CGGCTTTATCATAGCTCTCGT-3') [27], which differentiated the MED and MEAM1 species based on a microsatellite locus [28]. To confirm the MED species by PCR, the primer pair 2195Bt (5'-TGRTTTTTTTGGTCATCCRGAAGT-3') and C012/Bt-sh2 (5'-TTTACTGCACTTTCTGCC-3') were used [29]. All digested DNA was analyzed by agarose gel electrophoresis $(1.8 \%)$, stained with ethidium bromide, and visualized by UV transillumination [24].

\subsection{B. tabaci MEAM1 and MED Mass Rearing}

The virus-free cryptic species B. tabaci MED and MEAM1 were obtained from the col-lection held by the Research Group on Integrated Pest Management in Agriculture (AGRIMIP) at the School of Agronomy (FCA), São Paulo State University "Júlio de Mesquita Filho" (UNESP), Campus of Botucatu. The insects were kept and raised in an air-conditioned room $\left(26 \pm 2{ }^{\circ} \mathrm{C}\right.$, photophase of $14 \mathrm{~h}$, and RH of $\left.70 \pm 10\right)$. Kale (Brassica oleracea var. Acephala L.) was used as the host plant for B. tabaci MEAM1, and the hybrid sweet pepper variety (Capsicum annuum L.) Magali $\mathrm{R}$ was used as the host for B. tabaci MED.

Host plants were grown in $750 \mathrm{~mL}$ pots containing Carolina Soil ${ }^{\circledR}$ (Pardinho, SP, Brazil) commercial substrate, irrigated with $50 \mathrm{~mL}$ of $\mathrm{H} 2 \mathrm{O}$ /day, and fertilized as required by the culture. Plants for insect multiplication were replaced every 30 days, immediately after the emergence of adult insects.

\subsection{Treatments and Experimental Design}

The experimental design was randomized blocks, consisting of 3 treatments and 10 repetitions, totaling 30 plots, with 3 plants per plot. The effects on plants infested with B. tabaci MED, B. tabaci MEAM1, and non-infested plants (control) were analyzed.

\subsection{Description of the Site and Experiment Implementation and Conduction}

The study was conducted at the School of Agronomy, FCA/São Paulo State University "Júlio de Mesquita Filho", UNESP, Campus of Botucatu, located at an altitude of $800 \mathrm{~m}$ above sea level, with coordinates $22^{\circ} 52^{\prime} 20^{\prime \prime} \mathrm{S}$ and $48^{\circ} 26^{\prime} 37^{\prime \prime} \mathrm{W}$. The weather condi-tions of this region are warm temperate (mesothermal) humid (Cfa) (Koppen), with an average temperature in the hottest month above $22{ }^{\circ} \mathrm{C}$.

The experiment was conducted in an arc-shaped protected environment $(6 \mathrm{~m} \times 21 \mathrm{~m} \times 3 \mathrm{~m}$, $\mathrm{W} \times \mathrm{L} \times \mathrm{H}$ ), covered with a $150 \mu \mathrm{m}$ polyethylene film, and side windows with $50 \%$ shading screens.

Santa Adélia Super (Topseed ${ }^{\circledR}$ ) (Santo Antônio de Posse, SP, Brazil) tomato seedlings were sown in a $200 \mathrm{~mL}$ container, filled with commercial substrate (Carolina Soil ${ }^{\circledR}$ ), and protected with voile fabric to avoid infestation with insects. After 30 days of sowing, the tomato seedlings were transplanted in $10 \mathrm{~L}$ pots filled with soil, sand, and manure in a ratio of 1:1:1. The spacing between the plants was $1 \times 0.4 \mathrm{~m}$. At planting, the following 
were applied: $60 \mathrm{~kg} \cdot \mathrm{h}^{-1}$ of $\mathrm{N}$ (urea), $300 \mathrm{~kg} \cdot \mathrm{h}^{-1}$ of $\mathrm{P}_{2} \mathrm{O}_{5}$ (simple superphosphate), and $100 \mathrm{~kg} \cdot \mathrm{h}^{-1}$ of $\mathrm{K}_{2} \mathrm{O}$ potassium chloride $(\mathrm{KCl})$, and the covering treatment was carried out at $200 \mathrm{~kg} \cdot \mathrm{h}^{-1}$ of $\mathrm{N}$ and $120 \mathrm{~kg} \cdot \mathrm{h}^{-1}$ of $\mathrm{K}_{2} \mathrm{O}$. Drip irrigation was applied, with a distance of $0.2 \mathrm{~m}$ between drippers.

The plants were kept throughout the experiment in individual cylindrical cages (D: $0.6 \mathrm{~m}, \mathrm{H}: 1.5 \mathrm{~m})$, consisting of galvanized wire $(\mathrm{n} .18,1.24 \mathrm{~mm})$, wrapped in white agrotextile fabric $\left(17 \mathrm{~g} \mathrm{~m}^{2}\right)$. The luminosity inside the cultivation cages was 27,200 lux.

The plants were infested at 33 DAS (days after sowing), with a manual aspirator, when the plants had 5-6 defined leaves. The procedure consisted of removing adults from an infested host plant and transferring them to the tomato plant. The insects remained on the plant for four days, to produce an infestation; then, the adult insects were removed, and the plants were monitored to follow the stages of development of the insects.

\subsection{Variables Analyzed}

\subsubsection{Analysis of the Physiological Aspects of Tomato}

Gas exchange evaluations were performed using an infrared gas analyzer IRGA (Infra-Red Gas Analyzer, model Li-6400; LI-COR Biosciences, Lincoln, NE, USA) at 34 days after plant transplantation, when the $B$. tabaci nymphs reached the third stage of development. The measurements were made on a sunny day, from 07:30 to 09:00, at an ambient temperature of $20^{\circ} \mathrm{C}$. Gas exchange was analyzed using $\mathrm{CO}_{2}$ assimilation rate parameters $\left(\mathrm{A}, \mu \mathrm{mol} \mathrm{CO} \mathrm{Cm}^{-2} \mathrm{~s}^{-1}\right)$, transpiration rate $\left(\mathrm{E}, \mathrm{mol} \mathrm{H}_{2} \mathrm{O} \mathrm{m}^{-2} \mathrm{~s}^{-1}\right)$, stomatal conductance ( $g s$, $\left.\mathrm{mol} \mathrm{m}{ }^{-2} \mathrm{~s}^{-1}\right)$, and internal $\mathrm{CO}_{2}$ concentration in the leaf $\left(\mathrm{Ci}, \mu \mathrm{mol} \mathrm{CO} \mathrm{Col}^{-1}\right)$. The water use efficiency (WUE, $\mu \mathrm{mol} \mathrm{CO} 2\left[\mathrm{mmol} \mathrm{H}_{2} \mathrm{O}\right]^{-1}$ ) was determined from the relationship between $\mathrm{CO}_{2}$ assimilation and transpiration, and the apparent carboxylation efficiency (A/Ci) was established based on the $\mathrm{CO}_{2}$ assimilation (A) and the internal concentration of $\mathrm{CO}_{2}$ in the leaf $(\mathrm{Ci})[13,29]$.

For chlorophyll $a$ fluorescence, measurements were made on the third expanded leaf, counted from the apex of the plant, using a portable fluorometer coupled to the IRGA, in which the maximum fluorescence $\left(\mathrm{Fm}^{\prime}\right)$ and minimum fluorescence $\left(\mathrm{Fo}^{\prime}\right)$ were quantified under artificial light. Based on previous data, the maximum quantum efficiency of PSII ( $\mathrm{Fv} / \mathrm{Fm})$, PSII maximum efficiency $\left(\mathrm{Fv}^{\prime} / \mathrm{Fm}^{\prime}\right)$, coefficient of photochemical quenching ( $\left.\mathrm{qP}\right)$, non-photochemical extinction coefficient (NPQ), and apparent electron transport rate (ETR) were determined $[30,31]$.

\subsubsection{Biochemical Analyses in Tomato}

For biochemical analyses, expanded leaves, with no signs of senescence, were collected from the upper third of the plant. One leaf per plant was collected in each whitefly development phase (oviposition and second, third, and fourth instars), washed, placed in transparent plastic bags, identified, and wrapped in aluminum foil to prevent material degradation by light. The leaves were then subjected to freezing with liquid nitrogen for later maceration, placed in $15 \mathrm{~g}$ containers, and stored in a freezer at $-20^{\circ} \mathrm{C}$.

The extraction used for the enzymes POD and PPO consisted of weighing $300 \mathrm{mg}$ of the fresh sample, homogenized with $8 \mathrm{~mL}$ of $0.2 \mathrm{M}$ potassium phosphate buffer solution (pH 6.7), and centrifuged $6000 \times g$ at $5^{\circ} \mathrm{C}$ for $15 \mathrm{~min}$ (model Mikro 220R; Hettich). The POD (EC 1.11.1.7) activity was determined according to the method described by Lima et al. [32]. The $\mathrm{H}_{2} \mathrm{O}_{2}$ and phenol solutions were added to the crude extract, and the samples were placed in a water bath at $30^{\circ} \mathrm{C}$ for $5 \mathrm{~min}$. Readings were performed at $505 \mathrm{~nm}$ ab-sorbance, and POD activities were expressed as $\mu \mathrm{mol} \mathrm{H}_{2} \mathrm{O}_{2}$ decomposed. $\mathrm{min}^{-1} \mathrm{~g}^{-1} \mathrm{FW}^{-1}$. The activity of PPO (EC 1.10.3.1) was determined according to the methodology of Kar and Mishra [33], using catechol as a substrate. For the reaction, $300 \mu \mathrm{L}$ of enzymatic extract and $1.85 \mathrm{~mL}$ of $0.1 \mathrm{M}$ catechol were used. Afterwards, the tubes were placed in a water bath $\left(30^{\circ} \mathrm{C}\right.$ ) for $30 \mathrm{~min}$. Absorbance was measured at $395 \mathrm{~nm}$, and the results expressed in $\mu \mathrm{mol}$ catechol were transformed into $\mathrm{min}^{-1} \mathrm{~g}^{-1} \mathrm{FW}^{-1}$. 
The extract used for SOD (EC 1.11.1.6) consisted of $300 \mathrm{mg}$ of plant material macerated in liquid nitrogen and homogenized with $5 \mathrm{~mL}$ of $100 \mathrm{mmol}$ potassium phosphate L-1 (pH 7.5), supplemented with tetrasodium ethylenediaminetetraacetic acid (EDTA), di-thiothreitol (DTT), and polyvinylpyrrolidone (PVPP). After centrifugation $(6000 \times g$ at $4{ }^{\circ} \mathrm{C}$ ) for $20 \mathrm{~min}$, the supernatant was collected and stored in an amber bottle in a freezer at $-20{ }^{\circ} \mathrm{C}$.

The SOD content was determined using the methodology proposed by Sun et al. [34], with modifications. The reaction process consisted of pipetting $2 \mathrm{~mL}$ sodium phosphate buffer ( $\mathrm{pH} 7.8$ ), $50 \mu \mathrm{L}$ of the enzyme extract, $250 \mu \mathrm{L}$ of tetrazolium blue nitro chloride (NBT), $200 \mu \mathrm{L}$ of tetrasodium ethylenediaminetetraacetic acid, $250 \mu \mathrm{L}$ of methionine, and $250 \mu \mathrm{L}$ of riboflavin. The reaction took place at $25^{\circ} \mathrm{C}$ for $10 \mathrm{~min}$ in a chamber containing fluorescent lamps $(20 \mathrm{~W})$. The reaction was stopped when the lamps were turned off [35], and the absorbance was read at $560 \mathrm{~nm}$. The enzyme content was determined based on the inhibition of the reduction of tetrazolium blue nitro chloride, with the need to inhibit $50 \%$ of the photoreduction defined as one unit of activity, and the content of SOD was expressed as $\mathrm{U}$ of activity $\mathrm{g}^{-1} \mathrm{FW}^{-1}$.

The total phenol content was determined spectrophotometrically using the FolinCiocalteu reagent [36]. Fresh leaf samples (50 mg) were extracted in $4 \mathrm{~mL}$ of $80 \%$ methanol, acidified with $1 \%$ acetic acid $(80 / 19 / 1, \mathrm{v} / \mathrm{v} / \mathrm{v})$, homogenized, and placed in an ultrasonic bath for $20 \mathrm{~min}$ (model Q3.0/40A; Eco-Sonics). Then, the samples were centrifuged at $5000 \times g$ at $4{ }^{\circ} \mathrm{C}$ (model Mikro 220R; Hettich), and the supernatant was removed and retained. The extraction process was repeated, and the supernatants were pooled in an amber container. Absorbance was analyzed at $725 \mathrm{~nm}$, and the total phenol content was expressed as gallic acid equivalent $100 \mathrm{~g}^{-1}$ of fresh weight (mg GAE $100 \mathrm{~g}^{-1} \mathrm{FW}^{-1}$ ).

The total flavonoid content was determined using the methodology described by Popova et al. [37], with adaptations. Fresh leaf samples $(100 \mathrm{mg})$ were extracted in methanol and placed in an ultrasonic bath (model Q3.0/40A; Eco-Sonics) for $30 \mathrm{~min}$. In the samples, $1 \mathrm{~mL}$ of $5 \%$ aluminum chloride was added, homogenized, and placed in the dark. Subsequently, the reaction was centrifuged at $6000 \times g$ (model Mikro 220R; Hettich). The results were expressed as mg quercetin per $100 \mathrm{~g}^{-1}$ of fresh weight (mg QE $\left.100 \mathrm{~g}^{-1} \mathrm{FW}^{-1}\right)$.

\subsection{Statistical Analysis}

The results were subjected to exploratory analyses to assess the normality [38] and homogeneity of the data [39]. Analysis of variance (ANOVA) was performed and differences were compared (Control, MED, and MEAM1) using the Tukey's test at a significance level of $5 \%$ using the AGROESTAT software [40]. The variables analyzed were A, Gs, A/Ci, $\mathrm{Fv}^{\prime} / \mathrm{Fm}^{\prime}$, non-photochemical extinction coefficient, SOD, POD, PPO, and total phenols and flavonoids.

\section{Results}

\subsection{Physiological Aspects of Tomato}

Tomato plants infested with B. tabaci (MED and MEAM1) showed changes in physiological parameters such as A, Gs, A/Ci, Fv'/Fm', and non-photochemical extinction coef-ficient of PSII (Table 1 ) when compared to control plants.

Tomato plants infested with $B$. tabaci MED had a reduced rate of $\mathrm{CO}_{2}$ assimilation (liquid photosynthesis) (A) by $55.5 \%\left(7.09 \mu \mathrm{mol} \mathrm{CO} \mathrm{C}^{-2} \mathrm{~s}^{-1}\right)$ compared to control plants ( $f$ 26.73, 20, $p<0.0001$ ) (Table 1). However, this trend was not observed in plants infested with $B$. tabaci MEAM1.

Plants infested with $B$. tabaci MED had lower $g_{s}\left(0.13 \mathrm{~mol} \mathrm{~m}^{-2} \mathrm{~s}^{-1}\right)$ than plants infested with $B$. tabaci MEAM1, which had $g s$ of 0.40 molm $^{-2} \mathrm{~s}^{-1}$. However, there was no difference in $g s$ when comparing infested and non-infested plants $(f 13.05,20, p<0.001)$ (Table 1$)$. 
Table 1. Influence on physiological parameters caused by Bemisia tabaci (MED and MEAM1) in tomato.

\begin{tabular}{cccccc}
\hline Treatments & $\mathbf{A}$ & $\boldsymbol{g s}$ & $\mathbf{A} / \mathbf{C i}$ & $\mathbf{F v}^{\prime} / \mathbf{F m}^{\prime}$ & $\mathbf{N P Q}$ \\
\hline Control & $15.93 \pm 2.68 \mathrm{a}$ & $0.27 \pm 0.07 \mathrm{ab}$ & $0.05 \pm 0.01 \mathrm{a}$ & $0.57 \pm 0.03 \mathrm{ab}$ & $1.39 \pm 0.25 \mathrm{ab}$ \\
MED & $7.09 \pm 1.71 \mathrm{~b}$ & $0.13 \pm 0.09 \mathrm{~b}$ & $0.02 \pm 0.01 \mathrm{c}$ & $0.53 \pm 0.03 \mathrm{~b}$ & $1.56 \pm 0.21 \mathrm{a}$ \\
MEAM1 & $12.60 \pm 1.52 \mathrm{a}$ & $0.40 \pm 0.10 \mathrm{a}$ & $0.03 \pm 0.01 \mathrm{~b}$ & $0.60 \pm 0.04 \mathrm{a}$ & $1.06 \pm 0.14 \mathrm{~b}$ \\
\hline
\end{tabular}

Means followed by the same letter in the column do not differ statistically by the Tukey's test at $5 \%(p<0.05)$. Subtitles: $\mathrm{CO}_{2}$ assimilation rate $\left(\mathrm{A}, \mu \mathrm{mol} \mathrm{CO} \mathrm{Cm}^{-2} \mathrm{~s}^{-1}\right)$, stomatal conductance $\left(g s, \mathrm{~mol} \mathrm{~m}^{-2} \mathrm{~s}^{-1}\right]$, apparent carboxylation efficiency (A/Ci), maximum efficiency of PSII $\left(\mathrm{Fv}^{\prime} / \mathrm{Fm}^{\prime}\right)$, non-photochemical extinction coefficient (NPQ).

The A/Ci decreased by $40 \%(0.03 \pm 0.01)$ and $60 \%(0.02 \pm 0.01)$ in tomato plants in-fested with B. tabaci MED and MEAM1, respectively ( $25.95,20, p<0.0001)$ (Table 1 ).

Plants infested with B. tabaci MED showed a reduction of approximately $11 \%$ in $\mathrm{Fv}^{\prime} / \mathrm{Fm}^{\prime}$ when compared to plants infested with MEAM1 ( $f$ 6.14, 20, $\left.p<0.0145\right)$. This pa-rameter allows the analysis of the capacity of chlorophylls to absorb photons.

Tomatoes infested by the cryptic species MED showed a higher NPQ of $12 \%(1.56 \pm 0.21)$ than control plants $(1.39 \pm 0.25)(f 8.57,20, p<0.0049)$ (Table 1$)$. This increase in NPQ can prevent damage caused by stress due to excess energy in the photosynthetic appa-ratus. In this sense, the increase in NPQ induced by the feeding of $B$. tabaci can reduce the number of electrons flowing through photosynthesis, that is, reducing the stress due to excess light in photosystem II.

Plants infested with MED showed increased damage to the photosynthetic apparatus, causing reduced photosynthesis and stomatal conductance, and consequently, low instant carboxylation efficiency. Consequently, rubisco activity has an increased influence on the production of photoassimilates and biomass production.

\subsection{Biochemical Aspects of Tomato}

The tomato plants infested with B. tabaci (MED and MEAM1) and not infested (control) showed biochemical differences in the following parameters: POD, PPO, total phenols, and flavonoids in the analyzed instars, but did not differ in activity of the SOD enzyme (Table 2).

Table 2. Superoxide dismutase, peroxidase, polyphenol oxidase, total phenols, and flavonoids (mean \pm SD) in tomatoes infested by Bemisia tabaci MED and MEAM1 and non-infested tomatoes (control), at each instar of the insect.

\begin{tabular}{ccccccc}
\hline & Treatments & SOD & POD & PPO & Total Phenols & Flavonoids \\
\hline & Control & $41.03 \pm 0.13 \mathrm{a}$ & $0.15 \pm 0.00 \mathrm{a}$ & $173.38 \pm 21.79 \mathrm{c}$ & $126.55 \pm 13.97 \mathrm{~b}$ & $61.53 \pm 1.25 \mathrm{~b}$ \\
0 & MED & $40.99 \pm 0.34 \mathrm{a}$ & $0.17 \pm 0.01 \mathrm{a}$ & $239.49 \pm 5.34 \mathrm{~b}$ & $167.86 \pm 7.83 \mathrm{a}$ & $73.68 \pm 4.66 \mathrm{a}$ \\
& MEAM1 & $40.97 \pm 0.02 \mathrm{a}$ & $0.08 \pm 0.00 \mathrm{~b}$ & $389.13 \pm 5.34 \mathrm{a}$ & $150.81 \pm 4.85 \mathrm{a}$ & $63.82 \pm 5.87 \mathrm{ab}$ \\
\hline \multirow{2}{*}{2} & Control & $41.47 \pm 0.01 \mathrm{a}$ & $0.14 \pm 0.02 \mathrm{~b}$ & $106.76 \pm 7.14 \mathrm{c}$ & $121.76 \pm 13.97 \mathrm{~b}$ & $53.62 \pm 1.31 \mathrm{a}$ \\
& MED & $41.16 \pm 0.28 \mathrm{a}$ & $0.30 \pm 0.04 \mathrm{a}$ & $467.13 \pm 62.79 \mathrm{a}$ & $192.95 \pm 7.83 \mathrm{a}$ & $57.51 \pm 5.87 \mathrm{a}$ \\
& MEAM1 & $40.97 \pm 0.44 \mathrm{a}$ & $0.21 \pm 0.00 \mathrm{~b}$ & $323.91 \pm 22.31 \mathrm{~b}$ & $177.89 \pm 3.21 \mathrm{a}$ & $59.90 \pm 5.98 \mathrm{a}$ \\
\hline & Control & $41.16 \pm 0.28 \mathrm{a}$ & $0.13 \pm 0.00 \mathrm{~b}$ & $685.32 \pm 10.16 \mathrm{~b}$ & $164.45 \pm 2.58 \mathrm{~b}$ & $69.56 \pm 3.38 \mathrm{a}$ \\
& MED & $41.11 \pm 0.35 \mathrm{a}$ & $0.23 \pm 0.03 \mathrm{a}$ & $823.70 \pm 35.83 \mathrm{a}$ & $214.67 \pm 11.98 \mathrm{a}$ & $69.09 \pm 2.32 \mathrm{a}$ \\
& MEAM1 & $41.12 \pm 0.13 \mathrm{a}$ & $0.26 \pm 0.01 \mathrm{a}$ & $270.09 \pm 14.68 \mathrm{c}$ & $142.07 \pm 2.16 \mathrm{c}$ & $68.61 \pm 12.20 \mathrm{a}$ \\
\hline & Control & $41.18 \pm 0.22 \mathrm{a}$ & $0.18 \pm 0.01 \mathrm{~b}$ & $376.68 \pm 39.20 \mathrm{a}$ & $151.29 \pm 12.75 \mathrm{a}$ & $69.11 \pm 1.69 \mathrm{~b}$ \\
4 & MED & $41.08 \pm 0.01 \mathrm{a}$ & $0.22 \pm 0.00 \mathrm{~b}$ & $309.58 \pm 15.32 \mathrm{a}$ & $121.97 \pm 4.46 \mathrm{~b}$ & $65.68 \pm 0.78 \mathrm{c}$ \\
& MEAM1 & $41.29 \pm 0.11 \mathrm{a}$ & $0.31 \pm 0.03 \mathrm{a}$ & $299.62 \pm 65.53 \mathrm{a}$ & $143.45 \pm 5.91 \mathrm{a}$ & $72.60 \pm 1.23 \mathrm{a}$ \\
\hline
\end{tabular}

Means followed by the same letter in the column do not differ statistically by the Tukey's test at $5 \%(p<0.05)$. Subtitles: 0 -Oviposition, 2 -second instar, 3-third instar, 4 - fourth instar. Superoxide dismutase (SOD) $\left(\mathrm{U}\right.$ of activity g $\left.{ }^{-1} \mathrm{FW}^{-1}\right)$, peroxidase (POD) ( $\mu$ mol $\mathrm{H}_{2} \mathrm{O}_{2}$ $\mathrm{min}^{-1} \mathrm{~g}^{-1} \mathrm{FW}^{-1}$ ), polyphenol oxidase (PPO) $\left(\mu \mathrm{mol}\right.$ catechol $\left.\mathrm{min}^{-1} \mathrm{~g}^{-1} \mathrm{FW}^{-1}\right)$, total phenols $\left(\mathrm{mg}\right.$ of EAG $100 \mathrm{~g}^{-1} \mathrm{FW}^{-1}$ ), flavonoids (mg of EQ $100 \mathrm{~g}^{-1} \mathrm{FW}^{-1}$ ).

Plants infested with B. tabaci (MED and MEAM1) influenced POD activity at all developmental stages of the evaluated insects (Table 2). During oviposition, MEAM1 infested plants showed lower POD activity by $46 \%$ and $52 \%$ when compared to control and MED plants, respectively $(f 82.20,8, p<0.0001)$. 
In the second instar, plants infested with B. tabaci MED showed higher enzymatic activity (POD) $(f 23.78,8, p<0.0014)$ than the control and MEAM1 infected plants, at rates of $53 \%$ and $30 \%$, respectively. There was no statistically significant difference between plants not infested (control) and those infested with MEAM1 (Table 2).

For the third instar, the plants infested by the cryptic species of B. tabaci (MED and MEAM1) $(f 34.23,8, p<0.0005)$ showed no statistically significant difference between them, the only difference being between infested and non-infested plants. However, plants attacked by B. tabaci MEAM1 exhibited $42 \%$ higher POD activity at the fourth instar of insect development than control plants, and $29 \%$ higher activity than plants infested with MED at this stage $(f 42.89,8, p<0.0003$ ) (Table 2$)$.

During oviposition, plants infested with B. tabaci (MED and MEAM1) showed higher PPO enzyme activity than control plants ( $f 192.63,8, p<0.0001)$; however, the cryptic species MEAM1 had higher enzyme activity than the control and MED at approximately 55\% (173.38 $\mu \mathrm{mol}$ catechol $\left.\mathrm{min}^{-1} \cdot \mathrm{g}^{-1} \mathrm{FW}^{-1}\right)$ and 38\% $\left(239.49 \mu \mathrm{mol}\right.$ catechol $\mathrm{min}^{-1} \cdot \mathrm{g}^{-1} \mathrm{FW}^{-1}$, respectively).

In the second and third instars, plants infested with MED had higher PPO enzyme activity than those in the other treatments. In the second instar, tomato plants showed higher PPO activity, approximately $77 \%$ and $30 \%$ higher than the control and MEAM1 infested plants $(f 65.95,8, p<0.0001)$. In the third instar, plants infested with MED had higher PPO activity than the control and MEAM1 by $16 \%$ and $67 \%$, respectively $(f 466.21$, $8, p<0.0001)$.

During oviposition, infestation by the cryptic species resulted in greater production of total phenols than in control tomato plants, with a $19 \%$ and $32 \%$ increase for MEAM1 and $\operatorname{MED}(f 38.90,8, p<0.0004)$, respectively.

In the second and third instar, tomato plants infested with MED had a higher production of total phenols. In the second instar, there was no statistically significant difference between the two cryptic species analyzed, but tomato plants infested with MED had higher total phenol production than control plants $(f 30.54,8, p<0.0007)$ (Table 2$)$. In the third instar, MED infested plants had higher levels than the control and MEAM1 plants by 23\% and $34 \%$ ( $f 80.22,8, p<0.0001)$, respectively.

In the fourth instar, the tomato infested with MED had a lower content of total phenols compared to the control and plants infested with MEAM1 ( $f 9.52,8, p<0.0018)$ (Table 2). This may be related to the reduction of food in this phase [41].

As for the flavonoid content in the infested and control plants, there was a statistically significant difference only in the oviposition and fourth-instar nymph stages (Table 2). The plants attacked by MED showed higher levels of flavonoids than the control plants during oviposition; however, there was no difference between those infested with the cryptic species $(f 6.49,8, p<0.0316)$. In the fourth instar, the plants infested with MEAM1 had higher levels of flavonoids than those in the other treatments $(f 21.58,8, p<0.0018)$ (Table 2).

\section{Discussion}

\subsection{Physiological Aspects of Tomato}

Photosynthesis is indirectly affected by factors such as availability of water, $\mathrm{CO}_{2}$, light and temperature, these factors can directly interfere with the opening of the stomatal cleft. Tomato plants infested with B. tabaci (MED and MEAM1) presented interference in physiological parameters. However, between the cryptic species evaluated, the plants infested by MED had a greater reduction in $\mathrm{CO}_{2}$ assimilation, stomatal conductance, instantaneous carboxylation efficiency, and maximum PSII efficiency. It is important to note that these parameters are interdependent; thus, interference in one parameter can reflect on others.

The $g s$ was one of the parameters affected by the infestation of B. tabaci MED. Interference in $g s$ directly affects photosynthesis, as a reduction in gs causes resistance to $\mathrm{CO}_{2}$ 
uptake, and consequently lower $\mathrm{CO}_{2}$ concentration in the leaf mesophile, resulting in lower availability for chloroplasts and, therefore, lower production of photoassimilates [42-44].

When $g s$ is high, there is an increase in the $\mathrm{CO}_{2}$ assimilation rate depending on the use of internal carbon to maintain the variation of the chemical $\mathrm{CO}_{2}$ gradient, which allows entry into the leaf. Plants with lower $g s$ have a lower $\mathrm{CO}_{2}$ assimilation rate because the opening of the stomatal gap allows the entry of $\mathrm{CO}_{2}$ into the leaf mesophyll and a re-duction in water loss. Thus, the greater the limitation of $g s$, the lower is the carbon dioxide content in the leaf mesophyll, causing less substrate for the photosynthetic process, influ-encing the production of carbohydrates, and interfering with the development of plants. Reduced gs was also observed in citrus infested by Aleurocanthus woglumi (Ashby, 1915) (Hemiptera: Aleyrodidae) [45].

Changes in $g s$ are the main factors that affect the photosynthetic performance of plants, as they directly interfere with the instantaneous efficiency of carboxylation (A/Ci). There is a close relationship between $g s$ and $C i$, as they increase simultaneously. Furthermore, the instantaneous efficiency of carboxylation is directly related to the assimilation of $\mathrm{CO}_{2}$ and its intercellular concentration; therefore, the reduction in $\mathrm{A} / \mathrm{Ci}$ is owing to the lower rate of $\mathrm{CO}_{2}$ assimilation and, consequently, to the lower internal concentration of carbon dioxide in the leaf mesophile $[46,47]$.

Plants infested with $B$. tabaci MED showed a reduction in the maximum efficiency of PSII $\left(\mathrm{Fv}^{\prime} / \mathrm{Fm}^{\prime}\right)$, which is a parameter that allows the analysis of the capacity of chlorophylls to absorb photons. Furthermore, it reveals the physiological state of chlorophylls, which can interrupt the ability to absorb photons, reduce the production of ATP and NAD, and affect photosynthesis [48,49].

MED infestation had a high NQP, a process that seeks to avoid damage to the photosynthetic apparatus. In this process, unused energy is dissipated in a nonradioactive manner, increasing the NPQ. This increase in NPQ can prevent damage caused by stress due to excess energy in the photosynthetic apparatus. In this sense, the increase in NPQ induced by the feeding of $B$. tabaci can reduce the number of electrons flowing through photosynthesis, that is, reducing the stress due to excess light in photosystem II [48,50-52].

Another important factor to be mentioned is the influence of $B$. tabaci on photosynthetic parameters, which is a result of indirect and direct damage during feeding. This is because feeding causes a reduction in plant vigor, and the sugar released by insects that feed on the phloem promotes the development of fungi of Capnodium, on the surface of plants, hindering physiological processes such as photosynthesis, respiration and transpiration of parts attacked, which can block photosynthetically active radiation, causing a reduction of up to $70 \%$ of $\mathrm{CO}_{2}$ assimilation $[9,53]$. In this study, plants infested with $\mathrm{B}$. tabaci showed yellow spots on the leaves in places with nymphs. Furthermore, the presence of sugary exudates in the leaves was observed; however, little sooty mold was observed.

Plants infested with MED showed increased damage to the photosynthetic apparatus, causing reduced photosynthesis and stomatal conductance, and consequently, low instant carboxylation efficiency. Consequently, rubisco activity has an increased influence on the production of photoassimilates and biomass production.

\subsection{Biochemical Aspects of Tomato}

In the oviposition phase and second instar of B. tabaci MEAM1, the tomato showed reduced activity of the POD enzyme, which is an indicator of lower stress on the plants. This defense strategy against the tomato immune system is correlated with the secondary Hamiltonella endosymbionts, which cause the tomato to reduce the activity of POD enzymes, being a likely way to ensure that the offspring find the less lignified plant tissue, facilitating the insertion of the oral appliance [54].

Plants identify insect oviposition from exudates released during laying, through hypersensitivity responses, commonly necrosis, neoplasia, increase in reactive oxygen species and defense proteins. Plants can kill eggs by crushing them by cultivating new 
tissue at the laying site, or even killing them by synthesizing ovicidal substances [55]. These activities result in the death of insects yet at the egg stage $[55,56]$.

The third instar stage of the cryptic species of B. tabaci (MED and MEAM1) is the most harmful because of the suction of the phloem sap, which causes greater activity of the POD enzyme in tomato. The increased activity of this enzyme, caused by pest pressure, makes the attractive tissue less attractive to insects because of the transformation of phe-nols into quinone, and its participation in lignin synthesis, resulting in stiffness of the attacked tissue. The trend of increasing POD activity was maintained for MEAM1 in the fourth instar $[13,57]$.

As for the enzyme polyphenoloxidase (PPO), there was increased activity of this en-zyme in response to oviposition by B. tabaci MEAM1, and in the second and third instar of development of $B$. tabaci MED. The PPO enzyme is responsible for transforming phenolic compounds into reactive quinones, creating less attractive tissues for pests that feed on the tissue [12].

However, the greater PPO activity caused by B. tabaci MED demonstrated that tomato plants are tolerant to the attack by this cryptic species, as the greater the activity of the resistance enzymes POD and PPO, the greater was the defense of the plant against infestation by insects $[18,58]$.

Although PPO and POD transform phenols into quinone, POD is also involved in the biosynthesis of lignin and suberin [57], and the increased concentration of these substances hardens the cell wall, making it difficult to insert the mouth stylet of insects. Plants with higher production of antioxidant and defense enzymes (SOD, POD, PPO, CAT, and PAL) are considered more resistant. This trend was observed in peanuts showing higher enzyme activity and total phenol content, resulting in cultivars resistant to Helicoverpa armigera (Hübner, 1809), Spodoptera litura (Fabricius, 1775) (Lepidoptera: Noctuidae), and Empoasca kerri (Pruthi, 1940) (Hemiptera: Cicadellidae) [14]. Castor bean infested by Trialeurodes ricini (Misra, 1924) (Hemiptera: Aleyrodidae) also showed increased enzymatic activity [59].

Total phenols are important metabolites in tomato defense against herbivorous insects. These compounds inhibit insect feeding through their ability to provide toxicity, bind to soluble proteins, form non-digestible compounds, and inactivate enzymes in the insect digestive tract, which can lead to death [60]. Thus, plants with high levels of phenolic compounds may cause higher insect mortality, deformation of nymphs, or changes in biological parameters. In this sense, it was found that plants infested with B. tabaci (MED and MEAM1) had higher production of total phenols during oviposition and the second instar. In the third instar, plants attacked by MED showed high production of total phenols. This increase during oviposition is probably directly related to the increased activity of PAL, the first enzyme in the phenylpropanoid pathway, which is involved in the biosynthesis of phenols and salicylic acid (SA). This result was observed in Brassica folwwoing oviposition by Pieris brassicae (Linnaeus, 1758) (Lepidoptera: Pieridae), in which there was an accumulation of SA and the genes (EDS1 and NPR1), responsible for regulating the activity of the PAL enzyme, causing greater production of SA and, consequently, greater production of phenolic compounds [19,20,61].

The high content of flavonoids in tomatoes attacked by B. tabaci MED during oviposition relates to the detection by plants of the presence of eggs on the leaf surface and the anticipated response to future feeding by hatched insects. The high content of flavonoids produced are linked to the fluidity and rigidity of the cell membrane. Low levels of these compounds facilitated the feeding of insects in these plants, and therefore constituted an increased preference for oviposition by females of B. tabaci $[62,63]$. However, in the fourth instar, the highest flavonoid content was observed for MEAM1.

Based on the data presented here, we suggest that tomato is more susceptible to damage caused by B. tabaci MEAM1, due to its ability to suppress plant defense mechanisms. During oviposition, the ability of MEAM1 to interfere with the activity of the POD enzyme allows the offspring to have fewer lignified sites for insertion of the oral appliance. However, B. tabaci MED does not manipulate tomato defense; rather, it allows 
the activation of defense enzymes, which consequently can reduce infestation and host plant preference. It is likely that the ability to manipulate the defense caused by $B$. tabaci MEAM1 is related to the adaptation of this insect-pest to tomatoes in Brazil due to the time of adaptation, since the first report of MEAM1 occurred in the 1990s; while MED was registered just two decades later, in 2014. During that time, MEAM1 was forced to improve its attack strategies against the tomato defenses, currently having an adaptive advantage over MED.

\section{Conclusions}

Tomato plants infested with cryptic species of B. tabaci MED showed greater interference with their physiological and biochemical parameters than B. tabaci MEAM1. B. tabaci MED caused greater interference in the $\mathrm{CO}_{2}$ assimilation rate, stomatal conductance, and apparent carboxylation efficiency.

In terms of biochemical responses, tomato plants infested with B. tabaci MEAM1 showed lower POD enzyme activity, which may result in less lignified places for insertion of the insects' mouthparts, which may favor colonization by this cryptic species. As for MED, a shorter adaptation time may not have favored the development of strategies such as those presented by B. tabaci MEAM1.

Author Contributions: C.A.d.L.T. and R.C.d.O. contributed to conceptualization, data curation, formal analysis, methodology, validation, visualization, writing of the original draft, and writing for review and editing. C.A.d.L.T. also contributed to the investigation, while R.C.d.O. contributed to funding procurement, administration, and supervision of the project. F.d.S.P. contributed to curation, research, methodology, visualization, and data writing. M.D.O. and E.S.A. contributed to the study and methodology. S.S.J. contributed to conceptualization, investigation, data curation, methodology, validation, visualization, writing of the original draft, and writing for review and editing. G.P.P.L. contributed to data curation, methodology, validation, visualization and writing, original draft, and writing for proofreading and editing. All authors have read and agreed to the published version of the manuscript.

Funding: This study was funded by the Coordenação de Aperfeiçoamento de Pessoal de Nível Superior-Brazil (CAPES)-Financial Code 001. The authors would also like to thank the Conselho Nacional de Desenvolvimento Científico e Tecnológico (CNPq) and the Fundação de Amparo à Pesquisa do Estado de São Paulo (FAPESP) for financial support-Process 2020/02913-7 and 2018/18274-3.

Institutional Review Board Statement: Not applicable.

Informed Consent Statement: Not applicable.

Acknowledgments: The authors thank Fernando Javier Sanhueza Salas and the company FenixNet ${ }^{\circledR}$ for the donation of agrotextiles for making the cages. In addition, we thank the academics Rodrigo Martins and José Eduardo Berndt for their help in conducting the experiments.

Conflicts of Interest: The authors declare no conflict of interest.

\section{References}

1. FAOSTAT_Food and Agriculture Organization. 2021. Available online: http://www.fao.org/faostat/es/\#data/QC (accessed on 1 April 2021).

2. Mutisya, S.; Saidi, M.; Opiyo, A.; Ngouajio, M. Synergistic effects of agronet covers and companion cropping on reducing whiteflies infestation and improving yield of open field-grown tomatoes. Agronomy 2016, 6, 42. [CrossRef]

3. Kanakala, S.; Ghanim, M. Global genetic diversity and geographical distribution of Bemisia tabaci and its bacterial endosymbionts. PLoS ONE 2019, 14, e0213946. [CrossRef] [PubMed]

4. Shi, X.; Pan, H.; Xie, W.; Wang, S.; Wu, Q.; Chen, G.; Tian, L.; Zhou, X.; Liu, Y.; Zhang, Y. Different effects of exogenous jasmonic acid on preference and performance of viruliferous Bemisia tabaci B and Q. Entomol. Exp. Appl. 2017, 165, 148-158. [CrossRef]

5. Mugerwa, H.; Seal, S.; Wang, H.L.; Patel, M.V.; Kabaalu, R.; Omongo, C.A.; Alicai, T.; Tairo, F.; Ndunguru, J.; Sseruwagi, P.; et al. African ancestry of New World, Bemisia tabaci-whiteflies species. Sci. Rep. 2018, 8, 2734. [CrossRef]

6. De Moraes, L.A.; Muller, C.; Bueno, R.C.O.F.; Santos, A.; Bello, V.H.; De Marchi, B.R.; Watanabe, L.F.M.; Marubayashi, J.M.; Santos, B.R.; Yuki, V.A.; et al. Distribution and phylogenetics of whiteflies and their endosymbiont relationships after the Mediterranean species invasion in Brazil. Sci. Rep. 2018, 8, 14589. [CrossRef] [PubMed] 
7. Wang, Z.; Dai, P.; Yang, X.; Ruan, C.C.; Biondi, A.; Desneux, N.; Zang, L.S. Selectivity of novel and traditional insecticides used for management of whiteflies on the parasitoid Encarsia formosa. Pest Manag. Sci. 2019, 75, 2716-2724. [CrossRef] [PubMed]

8. Gilbertson, R.L.; Batuman, O.; Webster, C.G.; Adkins, S. Role of the insect supervectors Bemisia tabaci and Frankliniella occidentalis in the emergence and global spread of plant viruses. Annu. Rev. Virol. 2015, 2, 67-93. [CrossRef] [PubMed]

9. Tamilselvan, R.; Mahalingam, C.A.; Mohankumar, S.; Senguttuvan, K. Characterization of resistance mechanisms to the whiteflies, Bemisia tabaci Asia-II-8 (Hemiptera: Aleyrodidae) in cotton genotypes. Int. J. Trop. Insect Sci. 2020, 8, 373-381. [CrossRef]

10. Bonaventure, G. Plants Recognize Herbivorous Insects by Complex Signalling Networks. Annu. Plant Rev. 2018, 47, 1-35.

11. Xu, Y.; Qu, C.; Sun, X.; Jia, Z.; Xue, M.; Zhao, H.; Zhou, X. Nitric Oxide Boosts Bemisia tabaci Performance through the Suppression of Jasmonic Acid Signaling Pathway in Tobacco Plants. Front. Physiol. 2020, 11, 2-4. [CrossRef]

12. War, A.R.; Paulraj, M.G.; Ahmad, T.; Buhroo, A.A.; Hussain, B.; Ignacimuthu, S.; Sharma, H.C. Mechanisms of plant defense against insect herbivores. Plant Signal. Behav. 2012, 7, 1306-1320. [CrossRef]

13. Li, Q.; Tan, W.; Xue, M.; Zhao, H.; Wang, C. Dynamic changes in photosynthesis and chlorophyll fluorescence in Nicotiana tabacum infested by Bemisia tabaci (Middle East-Asia Minor 1) nymphs. Arthropod Plant Interact. 2013, 7, 431-443. [CrossRef]

14. War, A.R.; Munghate, R.S.; Sharma, H.C. Expression of different mechanisms of resistance to insects in groundnut under field conditions. Phytoparasit. 2015, 43, 669-677. [CrossRef]

15. Koch, K.G.; Chapman, K.; Louis, J.; Heng-Moss, T.; Sarath, G. Plant tolerance: A unique approach to control hemipteran pests. Front. Plant Sci. 2016, 7, 1363. [CrossRef] [PubMed]

16. Broetto, F.; Gomes, E.R.; Joca, T.A.C. O Estresse das Planta, 1st ed.; UNESP: São Paulo, Brazil, 2017; pp. 10-195.

17. Zhao, H.; Sun, X.; Xue, M.; Zhang, X.; Li, Q. Antioxidant enzyme responses induced by whiteflies in tobacco plants in defense against aphids: Catalase may play a dominant role. PLoS ONE 2016, 11, e0165454. [CrossRef] [PubMed]

18. Zhang, S.Z.; Hua, B.Z.; Zhang, F. Induction of the activities of antioxidative enzymes and the levels of malondialdehyde in cucumber seedlings as a consequence of Bemisia tabaci (Hemiptera: Aleyrodidae) infestation. Arthropod Plant Interact. 2008, 2, $209-213$. [CrossRef]

19. Bhonwong, A.; Stout, M.J.; Attajarusit, J.; Tantasawat, P. Defensive role of tomato polyphenol oxidases against cotton bollworm (Helicoverpa armigera) and beet armyworm (Spodoptera exigua). J. Chem. Ecol. 2009, 35, 28-38. [CrossRef] [PubMed]

20. Duan, L.; Liu, H.; Li, X.; Xiao, J.; Wang, S. Multiple phytohormones and phytoalexins are involved in disease resistance to Magnaporthe oryzae invaded from roots in rice. Physiol. Plant. 2014, 152, 486-500. [CrossRef] [PubMed]

21. Brown, J.K.; Frohlich, D.R.; Rosell, R.C. A batata-doce ou mosca-branca: Biótipos de Bemisia tabaci ou um complexo de espécies? Annu. Rev. Entomol. 1995, 40, 511-534. [CrossRef]

22. Costa, A.S.; Russell, L.M. Falha de Bemisia tabaci em reprodução em plantas de mandioca no Brasil (Homoptera: Aleyrodidae). Cienc. Culto. 1975, 27, 388-390.

23. Sun, D.B.; Liu, Y.Q.; Qin, L.; Xu, J.; Li, F.F.; Liu, S.S. Competitive displacement between two invasive whiteflies: Insecticide application and host plant effects. Bull. Entomol. Res. 2013, 103, 344-353. [CrossRef] [PubMed]

24. Bello, V.H.; Watanabe, L.F.M.; Fusco, L.M.H.; De Marchi, B.R.; Da Silva, F.B.; Gorayeb, E.S.; Moura, M.F.; De Souza, I.M.; Muller, C.; Salas, F.J.S.; et al. Outbreaks of Bemisia tabaci Mediterranean species in vegetable crops in São Paulo and Paraná States, Brazil. Bull. Entomol. Res. 2020, 110, 487-496. [CrossRef]

25. Watanabe, L.F.M.; Bello, V.H.; De Marchi, B.R.; da Silva, F.B.; Fusco, L.M.; Sartori, M.M.P.; Pavan, M.A.; Krause-Sakate, R. Performance and competitive displacement of Bemisia tabaci MEAM1 and MED cryptic species on different host plants. Crop. Prot. 2019, 124, 104860. [CrossRef]

26. Walsh, P.S.; Metzger, D.A.; Higuchi, R. Chelex 100 as a medium for simple extraction of DNA for PCR-based typing from forensic material. Biotech. 1991, 10, 506-513. [CrossRef] [PubMed]

27. De Barro, P.J.; Scott, K.D.; Graham, G.C.; Lange, C.L.; Schutze, M.K. Isolation and characterization of microsatellite loci in Bemisia tabaci. Mol. Ecol. Notes 2003, 3, 40-43. [CrossRef]

28. Kontsedalov, S.; Abu-Moch, F.; Lebedev, G.; Czosnek, H.; Horowitz, A.R.; Ghanim, M. Bemisia tabaci Biotype Dynamics and Resistance to Insecticides in Israel During the Years 2008-2010. J. Integr. Agric. 2012, 11, 312-320. [CrossRef]

29. Von Caemmerer, S.; Farquhar, G.D. Some relationships between the biochemistry of photosynthesis and the gas exchange of leaves. Planta 1981, 153, 376-387. [CrossRef]

30. Genty, B.; Briantais, J.M.; Baker, N.R. The relationship between the quantum yield of photosynthetic electron transport and quenching of chlorophyll fluorescence. Biochim. Biophys. Acta BBA Gen. Subj. 1989, 990, 87-92. [CrossRef]

31. Krall, J.P.; Edwards, G.E. Relationship between photosystem II activity and $\mathrm{CO}_{2}$ fixation in leaves. Physiol. Plant. 1992, 86, 180-187. [CrossRef]

32. Lima, G.P.P.; Brasil, O.G.; Oliveira, A.M. Poliaminas e atividade da peroxidase em feijão (Phaseolus vulgaris L.) cultivado sob estresse salino. Sci. Agrícola 1999, 56, 21-26. [CrossRef]

33. Kar, M.; Mishra, D. Catalase, Peroxidase, and Polyphenoloxidase Activities during Rice Leaf Senescence. Plant Physiol. 1976, 57, 315-319. [CrossRef] [PubMed]

34. Sun, Y.; Oberley, L.W.; Li, Y. A simple method for clinical assay of superoxide dismutase. Clin. Chem. 1988, 34, 497-500. [CrossRef] [PubMed]

35. Giannopolitis, C.N.; Ries, S.K. Superoxide dismutases: II. Purification and quantitative relationship with water-soluble protein in seedlings. Plant Physiol. 1977, 59, 315-318. [CrossRef] [PubMed] 
36. Singleton, V.L.; Rossi, J.A. Colorimetry of total phenolics with phosphomolybdic-phosphotungstic acid reagents. Am. J. Enol. Vitic. 1965, 16, 44-158.

37. Popova, M.; Bankova, V.; Butovska, D.; Petkov, V.; Nikolova-Damyanova, B.; Sabatini, A.G.; Marcazzan, G.L.; Bogdanov, S. Validated methods for the quantification of biologically active constituents of poplar-type propolis. Phytochem. Anal. Int. J. Plant Chem. Biochem. Tech. 2004, 15, 235-240. [CrossRef]

38. Shapiro, S.S.; Wilk, M.B. An analysis of variance test for normality (complete samples). Biometrika 1965, 52, 591-611. [CrossRef]

39. Bartlett, M.S. Properties of sufficiency and statistical tests. Proceedings of the Royal Society of London. Ser. A Math. Phys. Sci. 1937, 160, 268-282.

40. Barbosa, J.C.; Maldonado Junior, W. AgroEstat—Sistema Para Análises Estatísticas de Ensaios Agronômicos; FCAV/UNESP: Jaboticabal, Brazil, 2015; p. 396.

41. Perring, T.M.; Stansly, P.A.; Liu, T.X.; Smith, H.A.; Andreason, S.A. Sustainable Management of Arthropod Pests of Tomato: Whiteflies: Biology, Ecology, and Management; Academic Press: New York, NY, USA, 2018. [CrossRef]

42. Flexas, J.; Barón, M.; Bota, J.; Ducruet, J.M.; Gallé, A.; Galmés, J.; Jiménez, M.; Pou, A.; Ribas-Carbó, M.; Sajnani, C.; et al. Photosynthesis limitations during water stress acclimation and recovery in the drought-adapted Vitis hybrid Richter-110 (V. berlandieri $\times$ V. rupestris). J. Exp. Bot. 2009, 60, 2361-2377. [CrossRef] [PubMed]

43. Killi, D.; Haworth, M. Diffusive and metabolic constraints to photosynthesis in quinoa during drought and salt stress. Plants 2017, 6, 49. [CrossRef] [PubMed]

44. Taiz, L.; Zeiger, E.; Møller, L.M.; Murphy, A. Plant Physiology and Development, 6th ed.; Artmed: Porto Alegre, Brazil, 2017; pp. $1-888$.

45. Do Gomes, A.M.S.V.; de Reis, F.O.; de Lemos, R.N.S.; Mondego, J.M.; Braun, H.; Araujo, J. R.G. Physiological charactritics of citrus plants infested with citrus blackfly. Rev. Bras. Entomol. 2019, 63, 119-123. [CrossRef]

46. De Ferraz, R.L.S.; de Melo, A.S.; Suassuna, J.F.; de Brito, M.E.B.; Fernandes, P.D.; da Júnior, E.S.N. Trocas gasosas e eficiência fotossintética em ecótipos de feijoeiro cultivados no semiárido. Pesqui. Agropecuária Trop. 2012, 42, 181-188. [CrossRef]

47. Silva, F.G.; Dutra, W.F.; Dutra, A.F.; de Oliveira, I.M.; Filgueiras, L.M.B.; de Melo, A.S. Gas exchange and chlorophyll fluorescence of eggplant grown under different irrigation depths. Rev. Bras. Eng. Agrícola E Ambient. 2015, 19, 946-952. [CrossRef]

48. Maxwell, K.; Johnson, G.N. Chlorophyll fluorescence: A practical guide. J. Exp. Bot. 2000, 51, 659-668. [CrossRef]

49. Liu, L.; Zhu, B.; Wang, G.X. Azoxystrobin-induced excessive reactive oxygen species (ROS) production and inhibition of photosynthesis in the unicellular green algae Chlorella vulgaris. Environ. Sci. Pollut. Res. 2015, 22, 7766-7775. [CrossRef] [PubMed]

50. Kromdijk, J.; Głowacka, K.; Leonelli, L.; Gabilly, S.T.; Iwai, M.; Niyogi, K.K.; Long, S.P. Improving photosynthesis and crop productivity by accelerating recovery from photoprotection. Science 2016, 354, 857-861. [CrossRef] [PubMed]

51. Pan, C.; Ahammed, G.J.; Li, X.; Shi, K. Elevated $\mathrm{CO}_{2}$ Photosynthesis under high temperature by attenuating the functional limitations to energy fluxes, electron transport and redox homeostasis in tomato leaves. Front. Plant Sci. 2018, 9, 1739. [CrossRef]

52. Dai, C.; Qiu, L.; Guo, L.; Jing, S.; Chen, X.; Cui, X.; Yang, Y. Salicylic acid alleviates aluminum-induced inhibition of biomass by enhancing photosynthesis and carbohydrate metabolism in Panax notoginseng. Plant Soil 2019, 445, 183-198. [CrossRef]

53. Lopes, J.P.; Machado, E.C.; Deuber, R.; Machado, R.S. Análise de crescimento e trocas gasosas na cultura de milho em plantio direto e convencional. Bragantia 2009, 68, 839-848. [CrossRef]

54. Su, Q.; Oliver, K.M.; Xie, W.; Wu, Q.; Wang, S.; Zhang, Y. The whiteflies-associated facultative symbiont Hamiltonella defensa suppresses induced plant defences in tomato. Funct. Ecol. 2015, 29, 1007-1018. [CrossRef]

55. Hilker, M.; Fatouros, N.E. Resisting the onset of herbivore attack: Plants perceive and respond to insect eggs. Curr. Opin. Plant Biol. 2016, 32, 9-16. [CrossRef] [PubMed]

56. Geuss, D.; Stelzer, S.; Lortzing, T.; Steppuhn, A. Solanum dulcamara's response to eggs of an insect herbivore comprises ovicidal hydrogen peroxide production. Plant Cell Environ. 2017, 40, 2663-2677. [CrossRef] [PubMed]

57. Latournerie-Moreno, L.; Ic-Caamal, A.; Ruiz-Sánchez, E.; Ballina-Gómez, H.; Islas-Flores, I.; Chan-Cupul, W.; González-Mendoza, D. Survival of Bemisia tabaci and activity of plant defense-related enzymes in genotypes of Capsicum annuum L. Chil. J. Agric. Res. 2015, 75, 71-77. [CrossRef]

58. Zhang, J.; Wang, L.; Zheng, Y.; Feng, J.; Ruan, Y.; Diao, S.; Chen, S.; Jiang, B.; Shen, Z.; Lu, H. Effects of Bemisia tabaci (Gennadius) infestation and squash silverleaf disorder on Cucurbita pepo L. leaf. Sci. Hortic. 2017, 217, 8-16. [CrossRef]

59. Kurra, S.; Pathipati, U.R. Whiteflies, Trialeurodes ricini (Genn) feeding stress induced defense responses in castor, Ricinus communis L. plants. J. Asia Pac. Entomol. 2015, 18, 425-431. [CrossRef]

60. Harborne, J.B. The comparative biochemistry of phytoalexin induction in plants. Biochem. Syst. Ecol. 1999, 27, 335-367. [CrossRef]

61. Vlot, C.A.; Dempsey, D.A.; Klessig, D.F. Salicylic acid, a multifaceted hormone to combat disease. Annu. Rev. Phytopathol. 2009, 47, 177-206. [CrossRef] 
62. Scheidt, H.A.; Pampel, A.; Nissler, L.; Gebhardt, R.; Huster, D. Investigation of the membrane localization and distribution of flavonoids by high-resolution magic angle spinning NMR spectroscopy. Biochim. Biophys. Acta-Biomembr. 2004, 1663, 97-107. [CrossRef] [PubMed]

63. Su, Q.; Chen, G.; Mescher, M.C.; Peng, Z.; Xie, W.; Wang, S.; Wu, Q.; Liu, J.; Li, C.; Wang, W.; et al. Whiteflies aggregation on tomato is mediated by feeding-induced changes in plant metabolites that influence the behaviour and performance of conspecifics. Funct. Ecol. 2018, 32, 1180-1193. [CrossRef] 